\title{
Comparative Analysis of Technical Efficiency of Wheat Production in Row Planting and Broadcasting Methods: Empirical Evidence from Southern Ethiopia
}

\author{
Assefa Ayele Anaye ( $\square$ assefa.ayele50@gmail.com ) \\ Jimma University https://orcid.org/0000-0002-3212-7298 \\ Kassa Tarekegn Erkalo \\ Southern Agricultural Research Institute
}

\section{Research}

Keywords: Broadcasting, Cobb-Douglas, Hadiya zone, Row planting, SPF, Technical efficiency and Wheat

Posted Date: March 20th, 2020

DOl: https://doi.org/10.21203/rs.3.rs-18162/v1

License: (c) (1) This work is licensed under a Creative Commons Attribution 4.0 International License.

Read Full License 


\title{
Comparative Analysis of Technical Efficiency of Wheat Production in Row Planting and Broadcasting Methods: Empirical Evidence from Southern Ethiopia
}

\begin{abstract}
Introduction: Ethiopia is the largest wheat producer in Sub-Saharan Africa and wheat is one of the major staple food crops in many parts of the country. However, due to technical and socioeconomic factors the productivity of wheat is below the estimated potential. As a result of this the country remains a net importer of wheat. To improve this problem, row planting of wheat with improved level of efficiency becomes more crucial. This study was aimed to measure technical efficiency, yield gap due to inefficiency and identify the factors that influence the efficiency levels of wheat producers' row planting and broadcasting methods in Hadiya zone, southern Ethiopia. Cross sectional data from 203 farmers from both row planting and broadcasting methods were selected using multistage sampling procedure and analyzed using stochastic frontier Cobb-Douglas production.
\end{abstract}

Results and Conclusions: Descriptive results indicated that the average wheat output in row planting (3250 kg/ha) was $1360 \mathrm{~kg} / \mathrm{ha}$ higher than in broadcasting $(1890 \mathrm{~kg} / \mathrm{ha})$. The estimated results of the Cobb-Douglas frontier model shows that the mean technical efficiency was $83.4 \%$ and $57.8 \%$ under row planting and broadcasting respectively. About $646.882 \mathrm{~kg} / \mathrm{ha}$ under row planting and $1393.038 \mathrm{~kg} / \mathrm{ha}$ under broadcasting of wheat output was lost due to inefficiency. This reveals that under the existing practices there is a room to increase wheat yield more under broadcasting (42.2\%) than row planting (16.6\%) following the best-practiced farms in the study area. The SPF model indicates that NPS, urea, labor and seed, are significant determinants of wheat production level in both methods. The estimated SPF model together with the inefficiency parameters shows that education, age, fertility status of the plot, family size and extension contact negatively and significantly affected technical inefficiency whereas land fragmentation positively and significantly affected technical inefficiency of wheat farmers. Hence, emphasis should be given to improve the efficiency level of those less efficient farmers by adopting the practices of relatively efficient farmers in the area. Beside this, policies and strategies of the government should be directed towards the above mentioned determinants.

Keywords: Broadcasting, Cobb-Douglas, Hadiya zone, Row planting, SPF, Technical efficiency and Wheat 


\section{Introduction}

Ethiopia the second most populous country in Africa and more than $70 \%$ of population is still employed in the agricultural sector, but services have surpassed agriculture as the principal source of GDP. Currently, agriculture is contributes over 35.8\% to the national GDP, almost 90 percent of export and 72.7 percent of employment (CIA 2018).

Agricultural sector in is characterized by low productivity due to technical and socioeconomic factors. Mostly the farmers with the same resources are producing different per hectare output, because of management inefficiency inputs, limited use of modern agricultural technologies, obsolete farming techniques, poor complementary services such as extension, credit, marketing, and infrastructure; poor and biased agricultural policies in developing countries like as Ethiopia (FAO and WFP 2012).

Cereal production constitutes the largest sub-sector in the Ethiopian economy. It accounts for roughly 60 percent of rural employment, about 73 percent of the total cultivated land, and more than 60 percent of the total caloric intake of the country's population (Abu and Quintin 2013). Yield of cereals has been consistently well below world average and even of least developing countries average yield, indicating poor productivity of the crops in the country. According to (FAO 2011) the average cereal yield for the world and least developing countries were $3.71 \mathrm{t} / \mathrm{ha}$ and $2.02 \mathrm{t} / \mathrm{ha}$, respectively, while, the average cereal yield in Ethiopia was limited to $1.76 \mathrm{t} / \mathrm{ha}$.

Ethiopia is the largest wheat producer in Sub-Saharan Africa (MoANR 2016). Wheat is cultivated in the highlands of Ethiopia, mainly in Oromia, Amhara, Southern Nations Nationalities and Peoples' Region (SNNPR) and Tigray regions. It is predominantly grown by smallholder farmers under rain-fed conditions. Today, wheat used both as a source of food for consumers and as a source of income for farmers. Wheat and wheat products represent 14 percent of the total caloric intake in the country, making wheat the second-most important food, behind maize (19 percent) and ahead of teff, sorghum, and enset (10-12 percent each) (FAO 2015).

According to the report of Central Statistical Agency, for the crop year of 2016/2017, from the total land allocated for cereal crops, wheat stands in fourth by covering 13.49 percent of the total areas preceded by teff, maize, and sorghum. In the production year, the total area covered by wheat was 1.69 million hectares with a production of 4.52 million tonnes and yield 
of $2.68 \mathrm{t} / \mathrm{ha}$ from 4.99 million holders. In SNNP Region, the total area covered by wheat was 0.13 million hectare by 0.62 million private peasant holders; and the total production in tonnes in the same year was 3.29 million, and its average productivity was $2.58 \mathrm{t} / \mathrm{ha}$ (CSA 2018). The total production of wheat in Hadiya zone for the year 2016/17 was 0.11 million tonnes produced by 0.12 million private peasant holders who were engaged in wheat cultivation on 0.36 hectare. The average productivity was registered as $2.87 \mathrm{t} / \mathrm{ha}$ (CSA 2017).

Production of wheat has significantly increased over the past years. However, previous studies show that wheat farmers in Ethiopia produce on average 2.5t/ha, which is well below the experimental yield of above 5t/ha (Hailu 1991; MOA 2010, 2011, 2012 cited in Gebreselassie et al. 2017). According to Ethiopian Ministry of Agriculture, farm level productivity is $2.1 \mathrm{t} /$ ha using traditional broadcasting while potential yield stands at $2.45 \mathrm{t} / \mathrm{ha}$ (MoA, 2012). As a result of this the country remains a net importer of wheat and experiencing a huge gap between production (4.5 million tonnes) and consumption levels (5.4 million tonnes) in 2016, which results in import dependence. For instance, in 2016 the Ethiopian Grain Trade Enterprise imported 750 thousand tonnes from Russia and Argentina and 300 thousand tonnes through food aid, resulting in 1.05 million tonnes of imported wheat Brasesco et al. (2019).

Empirical studies in Ethiopia show that yields are very responsive to row planting for wheat production. Tolosa et al. (2014) reported average yield of 2.80t/ha (19.7\%) in the highland areas using row planting which is above national average yield of $2.45 \mathrm{t} / \mathrm{ha}$ in the country. The research systems together with other stakeholders have played a major role in delivering improved technologies for increasing productivity in the country (Biftu et al. 2016). In spite of these efforts, productivity is below the estimated potential. One major factor contributing to low productivity in the country is the low adoption rate of improved technologies (Hassen et al. 2012; Ahmed et al. 2014). Among these is the low adoption of row planting despite its ability to contribute to high yields (Joachim et al. 2013).

According to previous researches in Ethiopia, there also exists a wide cereal yield gap among the farmers that might be attributed to many factors such as lack of knowledge and information on how to use new crop technologies, poor management, biotic, climate factors and more others (Sisay et al. 2015; Milkessa et al. 2019; Tolossa et al. 2019). 
If the existing production system is not efficient, introduction of new technology could not bring the expected improvements in the productivity of wheat and other crops. Given the existing technology, improvements in the technical efficiency will enable farmers to produce the maximum possible output from a given level of inputs. Hence, improvements in the level of technical efficiency will increase productivity.

Agricultural extension activities have been concerned with the promotion, adoption and scaling up of wheat row planting practices; and adoption of the practice is seen as the factor for wheat yield enhancement in the country. As a result, manual planting of wheat in row has become one of the agronomic practices of smallholder farmers in the country. The conventional planting method, that is broadcasting seed by hand at high seed rates, reduce yield because uneven distribution of the seeds makes hand weeding and hoeing difficult, and plant competition with weeds lowers wheat growth and tillering. This causes wheat yield reduction. However, row planting with proper distance between rows and plant density allows for sufficient aeration, moisture, sunlight and nutrient availability leading to proper root system development Tolossa et al. (2014).

Therefore, from the perspective of formulating effective agricultural policies, undertaking empirical works on farm level technical efficiency has a paramount importance in providing valuable information to policy makers which will be used to enhance agricultural productivity. There have been various empirical studies conducted to measure technical efficiency of wheat producers in Ethiopia. But, none of them conducted their study on technical efficiency of wheat production under row planting and broadcasting methods. As to the best of the author's knowledge and belief, there were no similar studies undertaken in the study area. Moreover, the question that how much Hadiya zone wheat producers are technically efficient under broadcasting and row planting methods, what factors can significantly affect their efficiency? and yield gap due to inefficiency in the study area have not yet been answered. This study therefore was aimed to measure and compare farm level efficiency of wheat production using row planting and broadcasting methods, yield gap due inefficiency and respective factors affecting their efficiency in order to enable farmers to apply more efficient sowing method for wheat production. 


\section{Research methodology}

\subsection{Description of the study area}

Hadiya Zone is one of the administrative zones found in Sothern Nations Nationalities and Peoples Regional State of Ethiopia. The administrative center of Hadiya zone is Hosanna town, which is located $232 \mathrm{~km}$ southwest of Addis Ababa. The zone is bordered on the south by Kembata Tembaro, on the southwest by the Dawro zone, on the west by the Omo River which separates it from Oromia Region and the Yem Special Woreda, on the north by Gurage, on the northeast by Silte, and on the east by the Alaba zone. The altitude of the zone ranges from 501 to 3000 m.a.s.1 with the mean annual temperature ranging from $10.54^{\circ} \mathrm{c}$ to $22.54{ }^{\circ} \mathrm{c}$. Agro-ecology of the zone is classified as lowland 3.1\%, mid-highland 65.3\%, and highland $31.6 \%$ with an average annual rain fall ranging from 801 to $1400 \mathrm{~mm}$. The zone has about 1.66 million total populations, of whom $49.7 \%$ are male and $50.3 \%$ are female. It has a total area of 3, 46958.5 hectares (HZoANRs, 2017).

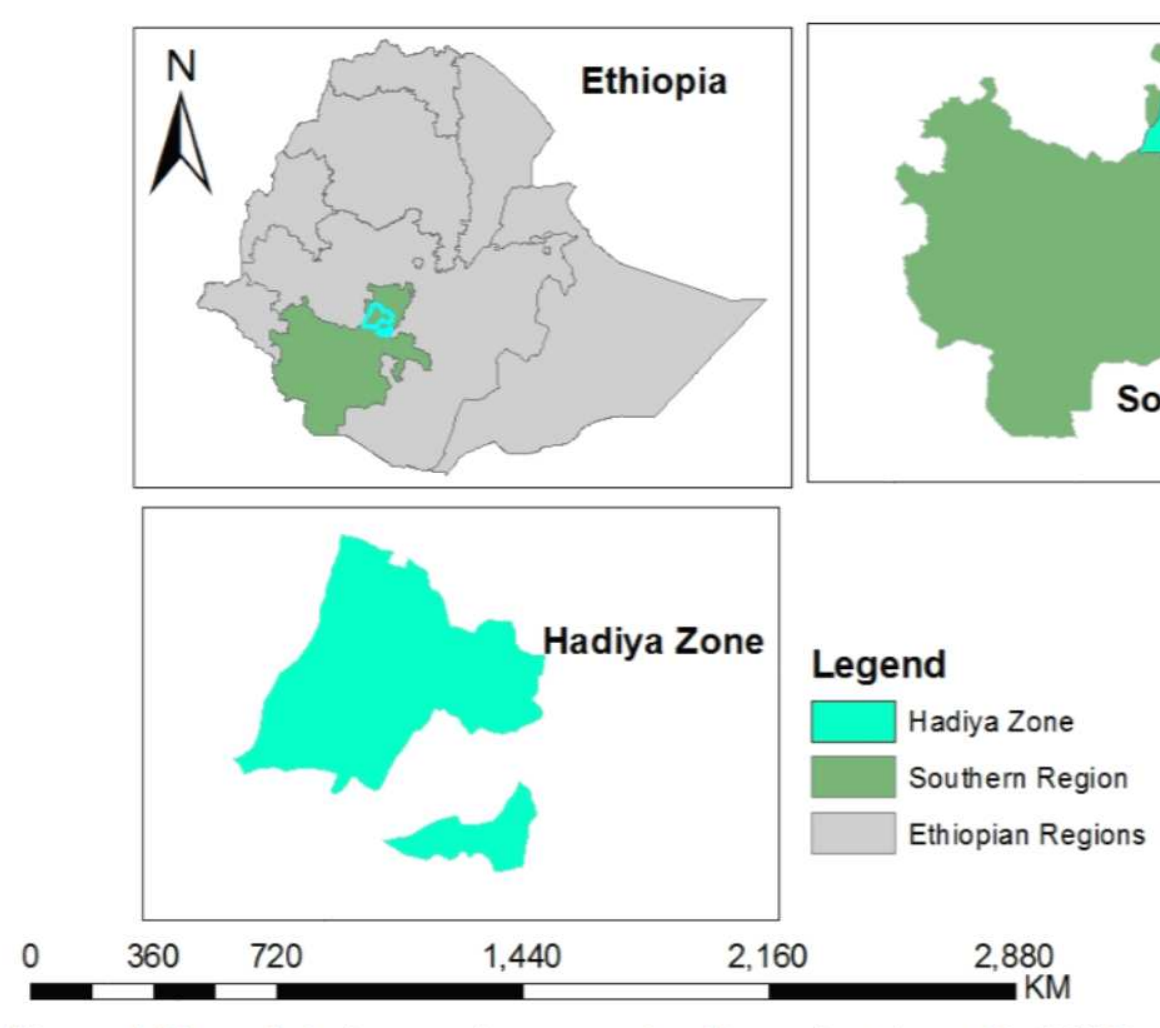

Figure 1 Map of study area (own construction using shapefile 2020) 
Farming system of the zone is mixed crop-livestock farming. The main types of crops grown are wheat, teff, barley, maize, sorghum. Wheat is the most important crop grown in terms of area coverage and the volume of production in the zone. Wheat being, one of the major crops grown in the study area, it is mostly used as staple food and as a source of income.

\subsection{Sampling technique and sample size determination}

Multi-stage sampling technique was employed for this study. In the first stage, the Hadiya zone was purposively selected based on the extent of wheat production. In the second stage, wheat producing districts in the zone were identified based on the extent of wheat production and two wheat producing districts namely Soro and Duna were selected randomly. In the third stage, three wheat producing kebeles (the small administrative unit in Ethiopia) from each of the two districts were selected randomly and fourthly, the households were stratified and listed in to two groups (households sowing wheat using row planting and broadcasting methods) in collaboration with each kebeles Development Agents (DA).

Finally, 203 sample farm households, 94 from row planting and 109 from broadcasting methods were selected by simple random sampling technique based on Probability Proportional to Size (PPS). The sample size was determined based on the following formula given by Yamane (1967).

$$
n=\frac{N}{1+N\left(e^{2}\right)}
$$

Where, $\mathrm{n}$ is sample size, $\mathrm{N}$ is number of wheat producing households using both methods within selected two districts which is 43,873 and e is the desired level of precision which was taken to be $7 \%$.

\subsection{Data types, sources and method of data collection}

In this study both primary and secondary data were used. The data set contained detailed information on households' socioeconomic and demographic characteristics, farm characteristics, input utilization, output produced and institutional related variables. The primary data were collected from randomly selected sample respondents using a structured questionnaire. In order to support primary data, secondary data were also collected from different published and unpublished documents about the study area from the zone's agricultural development offices, governmental and non-governmental agencies and websites. 


\subsection{Methods of data analysis}

\subsubsection{Descriptive analysis}

This method was used to summarize and analyze the sample households input use, output levels and their socio-economic, demographic and institutional characteristics, used in the frontier production and in the inefficiency model respectively. Descriptive statistical analysis was employed to analyze the survey data using measures of dispersion such as percentage, frequency and measures of central tendency such as mean and standard deviation.

\subsubsection{Econometric analysis}

Agricultural production is inherent to variability due to random shocks such as drought, weather, pest infection, fires, diseases, etc. Furthermore, because many farmers are smallholders whose farm operations are managed by family members, therefore keeping of accurate records is not always a priority. Thus much data available on production are likely to be subject to measurement errors (Tim and George, 1996). Due to these errors and random shocks which makes variation in output the stochastic production frontier will be used for its key features that the disturbance term is composed of two parts, a symmetric and a one sided component. The symmetric component captures the random effect outside of the control of the decision maker including the statistical noise contained in every empirical relationship particularly those based on cross- sectional household survey data. The one sided component captures deviations from the frontier due to inefficiency.

Therefore, the general stochastic frontier model developed independently by Aigner et al. (1977) and Meeusen and Broeck (1977) in which an additional random error, vi, is added to the non-negative random variable, $\mu_{\mathrm{i}}$, is specified as follows:

$$
\ln (y)=x_{i} \beta+v_{i}-\mu_{i}, \quad i=1,2, \ldots N
$$

There are different functional forms to represent the production frontier. The two commonly used functional forms are Cobb-Douglas and Translog, each having their merits and demerits. Both models overwhelmingly dominate the applications literature in stochastic frontier and econometric inefficiency estimation (Coelli et al. 2005). However, the work by Kopp and Smith (1980) confirmed that if the interest lies in measuring technical efficiency and not in the analysis of general structure of the production function, the functional form will have insignificant impact on measurement of efficiency. Cobb-Douglas is selected because the 
number of parameters involved would be so high if translog is specified. Thus Cobb-Douglas frontier function is specified as follows:

$$
\begin{aligned}
\operatorname{Ln}(\text { Output })= & \beta_{0}+\beta_{1} \ln (\text { Seed })+\beta_{2} \ln (N P S)+\beta_{3} \ln (\text { Urea })+\beta_{4} \ln (\text { Area }) \\
& +\beta_{5} \ln (\text { Labor })+\beta_{6} \ln (\text { Oxen })+\beta_{7} \ln (\text { Herbicide })+v_{i}-u i
\end{aligned}
$$

where output is the total output of wheat produced in $\mathrm{kg} / \mathrm{ha}$, seed is the total quantity of wheat seed used in kg/ha, NPS/Urea is the total amount of Nitrogen, Phosphorous and Sulphur (NPS) /urea fertilizer in $\mathrm{kg} / \mathrm{ha}$, area is the total area covered by wheat in hectares, labor is family and hired labor measured in man-days, oxen is the amount of draught power used in oxen day and herbicide is the total expenditure the farmer on herbicide purchase for wheat production and measured in Birr. $\mathrm{V}_{\mathrm{i}^{-}}$is the disturbance error term, independently and identically distributed as $\mathrm{N}\left(0, \sigma_{\mathrm{v}}{ }^{2}\right)$ intended to capture events beyond the control of farmers; and $\mu_{\mathrm{i}}$ - is a non-negative random variable, independently and identically distributed as $N\left(\mu, \sigma_{\mu}{ }^{2}\right)$ intended to capture technical inefficiency effects in the production of wheat measured as the ratio of observed output to maximum feasible output of the $\mathrm{i}^{\text {th }}$ household.

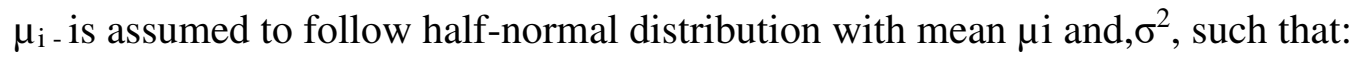

$$
\begin{aligned}
\mu_{i}= & \delta_{0}+\delta_{1} \text { Educ }+\delta_{2} \text { Sex }+\delta_{3} \text { Age }+\delta_{4} \text { Fert }+\delta_{5} \text { Slop }+\delta_{6} \text { Lives }+\delta_{7} \text { Fams } \\
& +\delta_{8} \text { Totcultlnd }+\delta_{9} \text { Frag }+\delta_{10} \text { Ownl }+\delta_{11} \text { Credit }+\delta_{12} \text { Exten }+w i
\end{aligned}
$$

The variables used in the above inefficiency model are defined as follows:

The subscript $\mathrm{i}$, indicates the $\mathrm{i}^{\mathrm{th}}$ household in the sample; $\mu \mathrm{i}$ is the inefficiency score; $\delta \mathrm{i}$ is a vector of parameter to be estimated; wi is error term. Educ represents the education level of the household farmer measured in continuous years of formal schooling; Sex is the sex of households which takes a value of 1 if the household head is male and zero, otherwise; Age represents the age of the household head in number of years; Fert represents the fertility status of the wheat plot, which would take a value 1 if the land is perceived fertile and 0 , otherwise; Slop represents the slope of the wheat plot takes 1 if the land is perceived plain and 0 otherwise; Lives is the total number of livestock in terms of Tropical Livestock Unit (TLU); Fams represents the number of household size; Totcultlnd represents the total land size operated by the farmer during the production year including his owned land, sharecropped lands and rented lands; Frag represents the number of plots of all annual crops the farmer 
managed during the production year including his own, hired and sharecropped; Ownl represents land owned by household, which would take a value of 1 if the land is his/her own or rented and 0 if the land is sharecropped; Credit represents access to credit for wheat production 1 if the household received credit, 0 otherwise; Exten represents frequency of extension contact, measured by the number of extension visits by extension agents in production season.

The one-stage estimation procedure of the inefficiency effects model together with the production frontier function was used in the study. In one-stage estimation, inefficiency effects are defined as an explicit function of certain factors specific to the firm, and all the parameters are estimated in one-step using the maximum likelihood procedure. The two-stage procedure produces inconsistency in the assumption (Coelli et al.1998). Moreover, one-stage procedure is the most commonly used method in the analysis of technical efficiency.

The maximum likelihood estimates for the parameters of the stochastic frontier are obtained using the FRONTIER 4.1 (Coelli 1996) computer program, in which the variance parameters are expressed in terms of

$$
\begin{gathered}
\sigma^{2}=\delta_{v}^{2}+\delta_{u}^{2} \\
\gamma=\frac{\sigma_{u}^{2}}{\left(\sigma_{v}^{2}+\sigma_{u}^{2}\right)}
\end{gathered}
$$

where $\sigma^{2}$ is the total variance of the model and the term represents the ratio of the variance of inefficiency's error term to the total variance of the two error terms defined above. The value of variance parameter ranges between 0 and 1 .

In the prediction of firm level technical efficiencies, Battese and Coelli (1995) pointed out that the best predictor of $\exp \left(-\mu_{\mathrm{i}}\right)$ is obtained by:

$$
E\left[\exp \left(-\mu_{i}\right) / e_{i}\right]=\frac{1-\phi\left(\sigma_{A}+\gamma e_{i}\right)}{1-\phi\left(\frac{\gamma e_{i}}{\sigma_{A}}\right)} \exp \left(\gamma e_{i}+\sigma^{2} / 2\right)
$$

where $\sigma_{A}=\sqrt{\gamma(1-\gamma) \sigma_{S}^{2}} ; \quad e_{i}=\ln \left(y_{i}\right)-x_{i} \beta ; \phi($.$) is the density function of a standard$ normal random variables. The farm-specific technical efficiency is defined in terms of observed output $\left(\mathrm{Y}_{\mathrm{i}}\right)$ to the corresponding frontier output $\left(\mathrm{Y}_{\mathrm{i}}\right)$ using the available technology derived from the result of the Equation 7 above as: 


$$
\mathrm{TE}_{i}=\frac{Y_{i}}{Y_{i}{ }^{*}}=\frac{\exp \left(x_{i} \beta-\mu_{i}\right)}{\exp \left(x_{i} \beta\right)}=\exp (-\mu i)
$$

TE takes value on the interval $(0,1)$, where 1 indicates a fully efficient farm. 


\section{Results and discussion}

\subsection{Descriptive statistics results}

Descriptive analysis results indicated that, average age of sample household heads was 46.28 years with a range of 26 to 67 years. This implies that most of the household heads were within their productive age. With regards to the sex of respondents, about $86.2 \%$ of the sample households were male headed. Education enhances the acquisition and utilization of information on improved technologies by farmers as well as their innovativeness. The educational level of the household head, on average, was 3.63 years with the minimum of zero and maximum of 12. Family labor plays an important part in the success of a smallholder farming practices in that the farmer does not need to spend too much money on labor costs. The average family size of the sampled household heads was 5.6 with the minimum of 2 and maximum of 8 .

From the total of about 146.5 hectares of land cropped during 2016/17 cropping season by sample farmers, most of the sample household (69.2\%) operated on their own land. Other than own land in the study area, farmers have other sources of land mainly through two informal arrangements, sharecropping and renting. Annual crops are sown in different plots and are fragmented and scattered over different places. A farmer on average has 2.27 plots with the number of plots varying from one to five. About $48.75 \%$ of the sample household heads perceived their wheat cultivated land as fertile.

In the study area, livestock has considerable role for household income and food security. The livestock holding was measures in terms of TLU. Sample farmers on average own livestock of 5.24 TLU and it ranges from 1.3 to 20.12 TLU. The survey result indicated that the average frequency of extension contacts during the production season in relation with wheat production was about 3.66 times with standard deviation of 1.96. In the production year, about $56.2 \%$ of the sample households used credit from different sources.

As indicated below Table 1 the average wheat output in row planting (3250 kg/ha) was $1360 \mathrm{~kg} / \mathrm{ha}$ higher than in broadcasting (1890 kg/ha). The average land allocated for wheat row planted was 0.67 ha and the average wheat broadcasted land was 0.74 ha. The result indicated that, on average, row planting increases human labor and oxen power requirement by $18.14 \%$ and $12.14 \%$ /ha, respectively, than broadcasting. Regarding fertilizer type, the most commonly and intensively used chemical fertilizer for the production of major cereal crops are 
NPS and Urea. The survey results revealed that wheat row planting minimizes the average NPS and Urea requirement by $31.33 \%$ and $29.02 \% /$ ha, respectively, than broadcasting. The others very important variable are seed and herbicide. The result also indicated that, on average row planting decreases the amount of seed and herbicide requirement by $23.59 \%$ and $12.97 \% /$ ha, respectively, than broadcasting.

Table 1 Summary statistics of variables for stochastic production function analysis Source: Own survey result (2019)

\begin{tabular}{llllll}
\hline Variables & \multicolumn{2}{c}{ Row planting } & & \multicolumn{2}{c}{ Broadcasting } \\
\cline { 2 - 3 } \cline { 5 - 6 } Mean & SE & & Mean & SE \\
Output (Kg/ha) & 3250 & 1974.65 & & 1890 & 1512.32 \\
Seed (Kg/ha) & 67.43 & 32.24 & & 83.33 & 44.35 \\
NPS (Kg/ha) & 56.78 & 25.12 & & 74.55 & 32.76 \\
Urea (Kg/ha) & 61.67 & 26.84 & & 79.57 & 36.55 \\
Area(ha) & 0.67 & 0.31 & & 0.74 & 0.37 \\
Human labor(man-day/ha) & 70.67 & 31.45 & & 59.82 & 21.91 \\
Oxen(oxen-day/ha) & 39.44 & 15.11 & & 35.17 & 10.45 \\
Herbicide(Birr/ha) & 158.33 & 80.73 & & 178.87 & 87.08 \\
\hline
\end{tabular}

\subsection{Econometric results}

\subsubsection{Hypotheses testing}

One attractive feature of stochastic production function method is that it is possible to test various hypotheses using maximum likelihood test ratio. Therefore, before presenting and discussing about parameter estimates of production frontier function and the inefficiency effects, it is advisable to run hypotheses tests in order to choose an appropriate model for further analysis and interpretation. Tests of hypothesis for the parameters of the frontier model are conducted using the generalized likelihood ratio statistics, $\lambda$, defined as:

$$
\lambda=-2\left[\log L\left(H_{O}\right)-\log L\left(H_{1}\right)\right]
$$

where, $\mathrm{L}(\mathrm{Ho})$ and $\mathrm{L}\left(\mathrm{H}_{1}\right)$ are the values of the log-likelihood function under the null and alternative hypotheses, $\mathrm{Ho}$ and $\mathrm{H}_{1}$, respectively. Tests of hypotheses for the parameters of the 
frontier model were conducted using the generalized likelihood ratio statistics, $\lambda$, defined by equation (9). Accordingly, the following hypotheses were tested, namely to select the correct functional form for the given data set, for the existence of inefficiency and finally for variables that explain the difference in efficiency.

Table 2 Summary of tests of the assumption of stochastic frontier approach. Source: Model output (2019)

\begin{tabular}{|c|c|c|c|c|c|}
\hline \multirow[b]{2}{*}{ Null hypothesis } & \multirow[b]{2}{*}{ DF } & \multicolumn{2}{|c|}{ Calculated $\chi^{2}(\mathrm{LR})$ value } & \multirow{2}{*}{$\begin{array}{l}\text { Critical } \\
\text { value }\end{array}$} & \multirow[b]{2}{*}{ Decision } \\
\hline & & Row planting & Broadcasting & & \\
\hline Ho: $\gamma=0$ & 1 & 48.55 & 53.34 & 6.63 & Reject \\
\hline Но: $\beta_{8}=\beta_{9}---=\beta_{35}=0$ & 28 & 38.46 & 40.88 & 48.27 & Not reject \\
\hline $\mathrm{H}_{0}: \mathrm{u}_{\mathrm{i}}=\delta_{1}=\delta_{2}=\ldots \delta_{12}=0$ & 12 & 67.74 & 59.58 & 26.21 & Reject \\
\hline
\end{tabular}

The first null hypothesis was $\mathrm{H}_{0}: \gamma=0$, which specifies that the inefficiency effects in the SPF were not stochastic. The generalized likelihood ratio statistics, $\lambda=48.55$ for row planting and 53.34 for broadcasting, presented in Table 2 are found to be greater than the critical value of 6.63. Hence, we reject null hypothesis $\left(\mathrm{H}_{\mathrm{o}}\right)$ at $1 \%$ level of significance showing that the average response function is not an adequate representation of the data. Consequently, the null hypothesis that wheat farmers in both methods in the area are fully efficient is rejected.

Similarly, the second test was the null hypothesis that identifies an appropriate functional form between restrictive Cobb-Douglas and the non-restrictive Translog production function which specifies that square and cross terms. The test result show that the calculated value of $\lambda$ $=38.46$ for row planting and 40.88 for broadcasting methods are less than the critical value of 48.27, thus the null hypothesis is not rejected at $1 \%$ level of significance implying that CobbDouglas functional form best fit the data set.

The next hypothesis is that the null hypothesis that the explanatory variables associated with technical inefficiency effects model are all zero, $\left(\mathrm{H}_{0}: \mathrm{U}_{\mathrm{i}}=\delta_{0}=\delta_{1}=\delta_{2}---\delta_{12}=0\right)$. To test this hypothesis likewise, $\lambda$ was calculated using the value of the log likelihood function under the stochastic frontier model (a model without explanatory variables of inefficiency effects, $\mathrm{H}_{0}$ ) and the full frontier model (a model with variables that are presumed to determine inefficiency of each farmer, $\mathrm{H}_{1}$ ). The calculated value of $\lambda=67.74$ and 59.58 for row planting 
and broadcasting respectively, are greater than the critical value of 26.21 , thus the null hypothesis that variables in the inefficiency effects model are simultaneously equal to zero is rejected at $1 \%$ level of significance. Hence, these variables explain the difference in inefficiency among farmers.

\subsubsection{Estimation of production function parameters}

The production function parameters were specified and estimated using the maximum likelihood method to analyze the technical efficiency of sample households in the production of wheat in row planting and broadcasting methods in Hadiya zone. The model comprises of twenty one parameters, seven of them were the explanatory variables of the stochastic frontier function while twelve of which were the explanatory variables that are hypothesized to influence the technical efficiency scores and the remaining two being the parameters associated with the distribution of $v_{i}$ and $\mu_{i}$.

The diagnostic statistics of inefficiency component reveals that sigma squared $(\sigma 2)$ was statistically significant which indicates goodness of fit, and the correctness of the distributional form assumed for the composite error term. The estimated value of Gamma $(\gamma)$ indicates that $54 \%$ under row planting and $78 \%$ under broadcasting of total variation in wheat output among sample farmers is due to technical inefficiency.

As the Table 3 depicts that the estimated coefficients for NPS, urea, human labor and seed are all positive and significant which confirm that, these inputs significantly increase output in both row planting and broadcasting methods. The MLE values of the coefficients can be interpreted as elasticity of production. The coefficients of inputs indicate that on average a $1 \%$ increase in NPS, Urea, human labor and seed increases the output of wheat by $0.15 \%, 0.13 \%$, $0.17 \%$ and $0.41 \%$, respectively under row planting and $0.12 \%, 0.14 \%, 0.11 \%$ and $0.33 \%$, respectively under broadcasting method. 
Table 3 Maximum likelihood (ML) estimate of stochastic production frontier for wheat farmers Source: Model output (2019)

\begin{tabular}{|c|c|c|c|c|}
\hline \multirow[t]{2}{*}{ Variables } & \multicolumn{2}{|c|}{ Row planting } & \multicolumn{2}{|c|}{ Broadcasting } \\
\hline & Coefficient & SE & Coefficient & $\mathbf{S E}$ \\
\hline Constant & $1.23 * *$ & 0.53 & $2.04 * * *$ & 0.75 \\
\hline Ln(Area) & 0.07 & 0.09 & 0.03 & 0.02 \\
\hline Ln(NPS) & $0.15 * *$ & 0.07 & $0.12 * *$ & 0.05 \\
\hline Ln(Urea) & $0.13^{* * *}$ & 0.04 & $0.14 * * *$ & 0.01 \\
\hline Ln(Labor) & $0.17 * * *$ & 0.05 & $0.11 * * *$ & 0.02 \\
\hline Ln(Oxen) & 0.04 & 0.09 & 0.14 & 0.10 \\
\hline Ln(Herbicide) & 0.08 & 0.05 & 0.18 & 0.21 \\
\hline $\operatorname{Ln}($ Seed $)$ & $0.41^{* *}$ & 0.19 & $0.33 * *$ & 0.14 \\
\hline Sigma-squared $\left(\sigma^{2}\right)$ & $0.21 * * *$ & 0.07 & $0.09 * * *$ & 0.03 \\
\hline $\operatorname{Gamma}(\gamma)$ & $0.54 *$ & 0.29 & $0.78 * * *$ & 0.27 \\
\hline Log likelihood Function & 30.78 & & 34.75 & \\
\hline
\end{tabular}

Note: $* * *$ and $* * *$ significant at $10 \%, 5 \%$ and $1 \%$ significance level, respectively.

\subsubsection{Yield gap due to inefficiency and technical efficiency scores}

The model output in (Table 4) indicated that, there was a variation in technical efficiency among sample households. The mean technical efficiency was $83.4 \%$ and $57.8 \%$ under row planting and broadcasting respectively; confirmed that, the average technical efficiency of Hadiya zone wheat producers is higher in row planting than broadcasting. This shows that there is a wide disparity among both methods wheat producer farmers in their level of technical efficiency which in turn indicates that, there exists a room for improving the existing level of wheat production through enhancing the level of farmers' technical efficiency. The mean level of technical efficiency further tells us that the level of wheat output of the sample 
respondents can be increased on average by about $16.6 \%$ under row planting and $42.2 \%$ under broadcasting if appropriate measures are taken to improve the level of efficiency of wheat growing farmers. In other words, on average the sample households decrease their inputs by $16.6 \%$ under row planting and $42.2 \%$ under broadcasting method to get the output they are currently getting.

The distribution of the technical efficiency scores as shown in the Figure 2, revealed that majority $(80.85 \%)$ of the sample farmers have TE score greater than or equal to $50 \%$ under row planting and about (56.88\%) of the sample farmers have TE score greater than or equal to $50 \%$ under broadcasting. That is why the distribution of the TE scores is skewed to the right for row planting and slightly normal distribution for broadcasting. Moreover, the frequencies of occurrences of the predicted technical efficiencies in range indicate that the highest number of household have technical efficiencies between 0.80-1under row planting and no farmer have technical score of more than 0.90 under broadcasting. All this again approved that, wheat producers more better technically efficient under row planting than broadcasting in the study area.

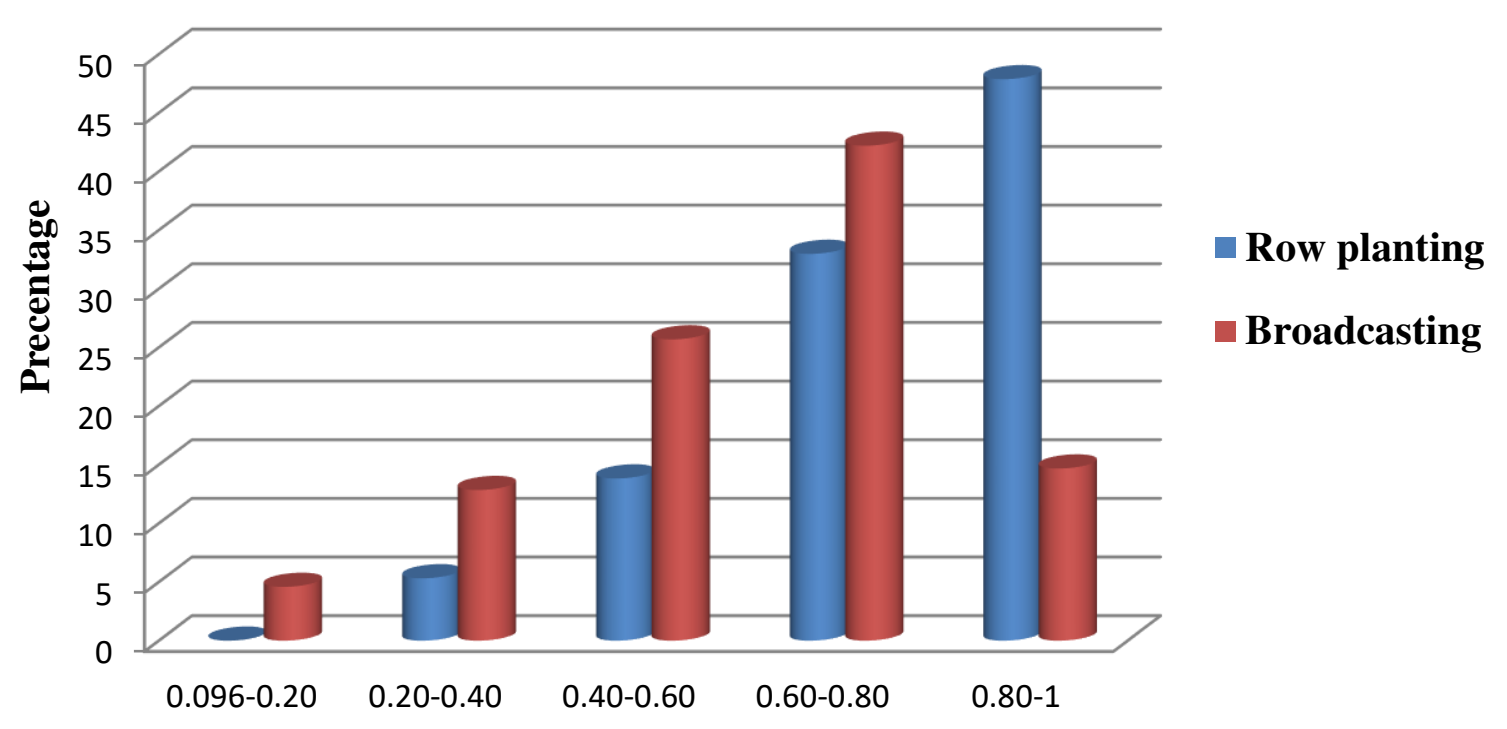

TE ranges

Fig. 2 Frequency distribution of technical efficiency Source: Own survey result (2019)

\subsection{Yield gap due to technical inefficiency}


Yield gap may be defined as the difference between technically full efficient yield and observed yield. Therefore, yield gap is the amount which represents fewer yields due to technical inefficiency. Based on Equation 3 above the potential wheat output was estimated for sample wheat producer farmers by dividing the actual individual level of wheat output by the predicted technical efficiency scores from stochastic frontier model. After calculating potential wheat output, the yield gap of wheat was estimated. Yield gap is estimated by the difference between technically full efficient yield and observed yield. The mean result is presented in Table 4 below.

It was observed that mean technical inefficiency was $16.6 \%$ under row planting and $42.2 \%$ broadcasting which caused $646.882 \mathrm{~kg} / \mathrm{ha}$ and $1393.038 \mathrm{~kg} / \mathrm{ha}$ yield gap of wheat on average, respectively. This shows that sample households in study area were producing on average $646.882 \mathrm{~kg} / \mathrm{ha}$ and $1393.038 \mathrm{~kg} / \mathrm{ha}$ lower wheat output than their potential yield under row planting and broadcasting methods, respectively. This shows that under the existing practices there is a room to increase wheat yield more under broadcasting than row planting following the best-practiced farms in the study area.

Table 4 Wheat yield gap due to technical inefficiency Source: Own survey result (2019)

\begin{tabular}{llllll}
\hline \multirow{2}{*}{ Variable } & \multicolumn{2}{c}{ Row planting } & & \multicolumn{2}{c}{ Broadcasting } \\
\cline { 2 - 3 } & Mean & SE & & Mean & SE \\
\hline Actual yield (kg/ha) & 3250 & 1974.653 & & 1908 & 1512.324 \\
TE estimates & 0.834 & 0.167 & & 0.578 & 0.184 \\
Potential/frontier yield (kg/ha) & 3896.882 & 2124.265 & & 3301.038 & 1867.076 \\
Yield gap/loss (kg/ha) & 646.882 & 149.612 & & 1393.038 & 354.752 \\
\hline
\end{tabular}

\subsubsection{Determinants of technical inefficiency of wheat producers}

After measuring levels of farmers' efficiency in wheat production and determining the presence of efficiency variation among farmers, finding out factors that affect efficiency levels among the sampled farmers was the next most important step of this study. Table 5 illustrates 
the socio-economic, demographic, farm characteristics and institutional factors that affect efficiency in wheat production. Out of the twelve variables used, six variables (education, age, fertility status of the plot, family size, land fragmentation and extension contact) were found to affect significantly the efficiency of wheat farmers.

Table 5 Maximum likelihood estimates of factors affecting technical inefficiency Source: Model output (2019)

\begin{tabular}{|c|c|c|c|c|}
\hline \multirow[t]{2}{*}{ Variables } & \multicolumn{2}{|c|}{ Row planting } & \multicolumn{2}{|c|}{ Broadcasting } \\
\hline & Coefficient & SE & Coefficient & SE \\
\hline Constant & $1.67 * * *$ & 0.15 & $2.98 * * *$ & 0.18 \\
\hline Education & $-0.02 * *$ & 0.01 & $-0.07 * * *$ & 0.02 \\
\hline Sex & -0.08 & 0.09 & -0.06 & 0.07 \\
\hline Age & -0.05 & 0.04 & $-0.02 *$ & 0.01 \\
\hline Fertility & $-0.18 * * *$ & 0.05 & $-0.10 * * *$ & 0.03 \\
\hline Slope & 0.02 & 0.03 & 0.07 & 0.06 \\
\hline Livestock & -0.13 & 0.09 & -0.05 & 0.04 \\
\hline Family size & -0.10 & 0.07 & $-0.14 * * *$ & 0.02 \\
\hline Total cultivated land & -0.02 & 0.05 & -0.04 & 0.09 \\
\hline Land fragmentation & $0.02 * *$ & 0.01 & $0.06 * * *$ & 0.02 \\
\hline Land ownership & -0.03 & 0.02 & -0.01 & 0.02 \\
\hline Credit & -0.04 & 0.05 & -0.04 & 0.05 \\
\hline Frequency extension contact & $-0.12 * * *$ & 0.02 & $-0.19 * * *$ & 0.06 \\
\hline Log likelihood Function & 30.78 & & 34.75 & \\
\hline
\end{tabular}

Note: $* * *$ and $* * *$ significant at $10 \%, 5 \%$ and $1 \%$ significance level, respectively.

Education status of household head influenced inefficiency negatively. Hence, education can be a proxy variable for managerial ability of the farmer and improves the ability of the household to make informed decision about production inputs. Educated farmers more often have better access to agricultural information and higher tendency to adopt and utilize 
improved inputs (like fertilizers and crop varieties) more optimally and efficiently. This result is in line with the findings of Sisay et al. (2015), Musa et al. (2015) and Milkessa et al. (2019).

Age of household head (which is a proxy variable for farming experience) had statistically significant and negative relationship with technical inefficiency of wheat production under broadcasting method. This indicates that as the age of farmers increases their inefficiency reduces which leads to improvement in the level of technical efficiency. This may be because farmers become more expert in different agronomic practices as they become experienced. The result is in conformity with the results of Alemu et al. (2018) and Assefa et al. (2019).

The estimation result indicates that planting wheat on fertile soils was found to significantly reduce technical inefficiency of wheat producers. This may be associated with those fertile lands require less commercial fertilizer application which leads to reduction in cost. This result is similar with the studies by Mamo et al. (2018) and Milkessa et al. (2019).

The negative coefficient of family size implies that an in increase in this variable would lead to decrease in the level of technical inefficiency wheat producers under broadcasting method. The reason for this was probably because broadcasting method demands more human labor than row planting. Since family labor is the main input in crop production as the farmer has large family size would manage crop plots on time and may able to use appropriate input combinations by using their own labor. This result is similar with the findings of Sorsie et al. (2015) and Tolossa et al. (2019).

The positive and significant value of the coefficient of fragmentation in Table 5 indicates that plots in the area are highly fragmented and scattered over many places that would make difficult to perform farming activities on time and efficiently. This may be because if the number of plots operated by the farmer increases; it may be difficult to manage these plots. Thus farmers that have large number of plots may waste time in moving between plots. This finding is in line with empirical findings of Milkessa et al. (2019) and Assefa et al. (2019).

Finally, as shown in Table 5, the study result also confirmed that the presence of more contact between extension agents and farmers made farmers more technically efficient. Extension services are assumed to help in dissemination and adoption of new technologies. In addition, this extension services offer guidance to the farmers related to the use of various resources and provide consultancy services in managing their scarce resources more 
efficiently. The findings are consistent with earlier results of Sisay et al. (2015) and Tolossa et al. (2019). 


\section{Conclusions and recommendations}

The difference between actual agricultural production and potential for increasing its productivity still persists in Ethiopia. To address this, it needs boosting of agricultural productivity and improves living standard of farmers either through use of modern inputs technology or decreasing the present level of inefficiency. Thus it is possible raise productivity through improving efficiency by using existing resource base and available technology. Therefore, this study was conducted to estimate technical efficiency of wheat producer farmers under row planting and broadcasting methods in Hadiya zone, Southern Ethiopia.

The findings of this study, confirmed that there is a room to enhance production and productivity by improving the technical efficiency of wheat production more under broadcasting method than row planting, given same level of input and current technology. The estimated stochastic frontier Cobb-Douglas production function indicates that the amount of NPS, Urea fertilizers, human labor and seed had a positive and significant effect on the level of wheat production under both methods. The positive coefficient of these parameters indicated that increased use of these inputs up to the recommended level increases the production level. The results also confirmed that, the estimated SPF model together with the inefficiency parameters shows that education status, age, fertility status of the plot, family size, and frequency extension contact were found to significantly and negatively affect the level of technical inefficiency of wheat producer farmers while land fragmentation was found to significantly and positively affect the level of technical inefficiency of wheat producer farmers in both methods.

Therefore, providing formal and informal type of farmers' education by using the available human and infrastructural facilities like extension agents and farmers training centers. The local government should arrange field days, cross-visits, creating forum for experience sharing elder households and provision of short-term training programs so as to share the knowledge of elder households to young farmers. Development programs need to strengthen improved land management practices to improve and maintain the fertility of farm land to increase efficiency of farmers. Finally, farmers that operated larger number of plots are less efficient than others. This implies that land policy that favor consolidated land holding increase the efficiency of farmers. 


\section{Abbreviations}

CSA: Central statics agency; DF: Degree of freedom; FAO: Food and agriculture organization;

GDP: Gross domestic product; $\mathrm{LH}_{0}$ : Log likelihood ratio of null hypothesis; $\mathrm{LH}_{1}$ : $\log$ likelihood ratio of alternative hypothesis; LR: Log likelihood ratio; NPS: Nitrogen, phosphorous and sulphur; SPF: Stochastic production function; TE: Technical efficiency; SNNP: Sothern nations, nationalities and peoples; WFP: World food program

\section{Acknowledgements}

The authors feel great to express their heartfelt thanks to enumerators and respondent farmers for sparing their precious time and for responding positively to the lengthy interview schedule. We gratefully acknowledge Southern Agricultural Research Institute (SARI) for their financial support. Finally, we wish to express our appreciations to the Areka Agricultural Research Center for their logistic support.

\section{Authors' contributions}

AA contributed in research proposal writing, data collection, data analysis, data interpretation and article writing. KA contributed in data interpretation and article writing. Both authors read and approved the final manuscript.

\section{Funding}

This study was funded by Southern Agricultural Research Institute (SARI), Ethiopia

\section{Availability of data and materials}

All authors declare that the data sets used in this manuscript are fully available upon request from the corresponding author.

\section{Competing interests}

We declare that we do not have competing interests. 


\section{References}

Abu T, Quintin G (2013) Ethiopia grain and feed annual report. Report Number: ET 1301.http://gain.fas.usda.gov/Recent\%20GAIN\%20Publications/Grain\%20and\%20Fe d\%20Annua 1_Addis\%20Ababa_Ethiopia_4-17-2012.pdf (Accessed 25 September 2019)

Ahmed H, Lemma Z, Endrias G (2014) Technical efficiency of maize producing farmers in Arsi Negelle, central rift valley of Ethiopia: Stochastic frontier approach. Journal of Agriculture and Forestry 60(1):157-167

Aigner DJ, Lovell AK, Schmidt P (1977) Formulation and estimation of stochastic frontier production function models. Journal of Econometrics 6:21-37

Alemu MD, Tegegne B, Beshir H (2018). Technical efficiency in Teff (Eragrostisteff) production: the case of smallholder farmers in Jamma district, South Wollo Zone, Ethiopia. J Agric Econ Rural Dev 4(2):513-9

Assefa A, Jema H, Bosena T (2019) Technical efficiency of wheat production by smallholder farmers in Soro district of Hadiya zone, Southern Ethiopia. East African Journal of Sciences 13(2):113-120

Battese G, Coelli T (1995) A model for technical inefficiency effects in a stochastic frontier production function for panel data. Empirical Economics, 20: 325-332

Biftu A, Diriba B, Bayisa T, Getachew F (2016) Participatory demonstration and evaluation of bread wheat technologies: The experience of FRG/FREG approach in Bale and West Arsi zones of Oromia national regional state, Ethiopia. Scientific Journal of Crop Science 5(3):90-103

Brasesco F, Asgedom D, Sommacal V, Casari G (2019) Strategic analysis and intervention plan for wheat and wheat products in the Agro-Commodities Procurement Zone of the pilot Integrated Agro-Industrial Park in Central-Eastern Oromia, Ethiopia. Addis Ababa. FAO. 104 pp. Licence: CC BY-NC-SA 3.0 IGO

Coelli TJ (1996) A guide to FRONTIER version 4.1: a computer program for frontier production and cost function estimation, CEPA Working paper 96/07, University of New England, Armidale

Coelli T, Rao D, Battese G (1998) An introduction to efficiency and productivity analysis. Kluwer Academic Publishers, Boston, Dordrecht/London, P, 134 - 249 
Coelli T, Rao D, O’Donnell C, Battese G (2005) An introduction to efficiency and productivity analysis $2^{\text {nd }}$ edition. New York: Springer

CSA (Central Statistical Agency) (2017) Agricultural sample survey 2016/2017 (2009 E.C).volume I report on area and production of major crops (private peasant holdings, Meher season), Addis Ababa

CSA (2018) Agricultural sample survey 2017/2018; report on area and production of major crops, vol I, CSA, Addis Ababa

CIA (Central Intelligence Agency) (2018) The work of a nation, Ethiopian economy profile. CIA world fact book, January 20, 2018

FAO (Food and Agricultural Organization) (2011) Food balance sheets database. Food and Agriculture Organization. http://faostat.fao.org (Accessed 18 October 2019)

FAO (Food and Agriculture Organization) (2015) FAOSTAT database. Accessible online (http://faostat3.fao.org/download/FB/FBS/E)

Gebreselassie S, Haile M, Kalkuhl M (2017) The wheat sector in Ethiopia: Current status and key challenges for future value chain development, ZEF Working Paper Series, No. 160, University of Bonn, Center for Development Research (ZEF), Bonn

Getachew W (2017) Economic efficiency of barley production: the case of smallholder farmers in Meket district, Amhara National Regional State, Ethiopia. MSc Thesis, Haramaya University

Hassen B, Bezabih E, Belay K, Jema H (2012) Determinants of chemical fertilizer technology adoption in north eastern highlands of Ethiopia: The double hurdle approach. Journal of Research in Economics and International Finance 1(2):39-49

HZoANRs (Hadiya Zone office of Agriculture and Natural Resources) (2017) Annual report on the overall agricultural statistics and status of zonal agricultural sector No.213 Hossana, Ethiopia

Jemal Y, Mengistu K, Wassu M, Tesfaye L, Kibebew K, Nega A, Kidesena S, Nigussie A, (2016) Proceeding of the national workshop on 'building resilience and reducing vulnerability in moisture stress areas through climate smart technologies and innovative practices', January 15-16, Haramaya University, Ethiopia 
Joachim V, Mekdim D, Bart D, Lemayehu S (2013) Scaling-up adoption of improved technologies: The impact of the promotion of row planting on farmers' teff yields in Ethiopia. LICOS discussion paper series pp. 1-2.

Kopp R, Smith V (1980) Frontier production function estimates for steam electric generation. Southern Economic Journal 47: 1049-1059

Mamo T, Getahun W, Chebil A, Tesfaye A, Debele T, Assefa S, Tesfaye S (2018). Technical efficiency and yield gap of smallholder wheat producers in Ethiopia: A Stochastic Frontier Analysis. African Journal of Agricultural Research 13(28):1407-1418

Meeusen W, Broeck JVD (1977) Efficiency estimation from Cobb-Douglas production functions with composed error. International Economic Review 18:435-444

Milkessa A, Endrias G, Fikadu M (2019) Economic efficiency of smallholder farmers in wheat production: the case of Abuna Gindeberet district, Oromia National Regional State, Ethiopia. Open Acc J Agri Res: OAJAR-100013

MoANR (Ministry of Agriculture and Natural Resources) (2016) Crop variety register issue No. 18, Addis Ababa, Ethiopia

Musa H, Lemma Z, Endrias G (2015) Measuring technical, allocative and economic efficiency of maize production in subsistence farming: Evidence from the Central Rift Valley of Ethiopia. Applied Studies in Agribusiness and Commerce. doi: 10.19041

Sisay D, Jema H, Degye G, Abdi-Khalil E (2015) Technical, allocative, and economic efficiency among smallholder maize farmers in Southwestern Ethiopia. Journal of Development and Agricultural Economics 7(8):283-292

Sorsie D, Nicolette M, Janus H (2015) Analysis of factors affecting technical efficiency of smallholder maize farmers in Ethiopia, Conference Paper

Tim C, George B (1996) Identification of factors which influence the technical inefficiency of Indian farmers. Austria Journal Agricultural Economics 40(2):103-128

Tolesa A, Bezabih E, Jema H, Belaineh L (2014) Impact of wheat row planting on yield of smallholders in selected highland and lowland areas of Ethiopia. International Journal of Agriculture and Forestry 4(5):386-393. https://doi.org/ 10.5923/j.ijaf.20140405.07

Tolossa T, Temesgen K, Zekrias S (2019) Economic efficiency of smallholder farmers in maize production in Gudeya Bila district, Oromia National Regional State, Ethiopia. Journal of Applied Agricultural Economics and Policy Analysis 2(1):1-7 
Yamane TI (1967) Statistics: An Introductory Analysis 2nd Edition. New York, Harper and Row 